\title{
Mortality of workers in a French asbestos cement factory 1940-82
}

\author{
A M ALIES-PATIN AND A J VALLERON \\ Unité de Recherches Biomathématiques et Biostatistiques, INSERM U 263 et Université Paris 7, 75251 Paris \\ Cedex 05, France
}

ABSTRACT The mortality of a complete cohort of 1506 French asbestos cement workers employed for at least five years is related to the time elapsed since first exposure. The mortality from all causes (analysed by the "man-years method") has been found to be above normal only in those subjects employed for more than 20 years, with more than 35 years of follow up. Standardised mortality ratios for cancers of all sites (ICD 140-209) and pulmonary cancer (ICD 162163.0) have been assessed in subjects whose first exposure dates go back more than 20 years. Mortalities from cancer of all sites and from pulmonary cancer have been detected in excess in workers employed for more than 20 years and originally hired when aged 25 or under.

Several epidemiological studies in the past 15 years have shown evidence of an excess mortality due to different cancers in asbestos workers: the tumours associated with exposure to asbestos include mesotheliomas,' bronchogenic carcinoma ${ }^{2}$ for which the carcinogenic role of asbestos has been shown, ${ }^{34}$ and tumours of the gastrointestinal tract, ${ }^{2}$ where there is doubt concerning the causal role of asbestos, ${ }^{5}$ although in some cases peritoneal mesotheliomas have been classified as cancer of the pancreas $^{16}$ and, finally, cancer of the laryn $x^{2}$ where contradictory results have been found. ${ }^{4} 7$

Most of the early studies in this area were carried out on workers handling pure asbestos, ${ }^{89}$ and few have been undertaken on workers handling asbestos cement. Hughes and Weill have detected an excess of respiratory cancer mortality in workers with moderate and heavy exposure ${ }^{10}$ and Henderson and Enterline have observed a high risk of respiratory cancers in workers engaged in manufacturing asbestos cement tubes." Lacquet and Van Der Linden showed evidence of excess mortality only from gastrointestinal cancer ${ }^{12}$ whereas Finkelstein has observed an excess mortality from all causes and a high excess of mortality from cancer of all sites (relative risk y 5) as well as from lung cancer (relative risk y 8$).{ }^{13}$

The fact that we were able to provide further data on this subject, despite the anonymity of death certificates that, in France, limits such studies, led us

Received 14 May 1984

Accepted 2 July 1984 to investigate the mortality of workers at an asbestos cement factory.

\section{Materials and methods}

Our study consists of assessing the risk of mortality from all causes in a cohort of asbestos cement workers and of the risk of mortality from cancer of all sites (ICD 140-209) and pulmonary cancer-that is, lung and pleural cancers: ICD 162-163.0 -in those subjects whose elapsed time since first exposure is greater than 20 years, "in order to maximise the possibility of detecting carcinogenic risk." 10

The factory is at Paray-Le-Monial in the centre of France. It was founded in 1940 and manufactures corrugated or flat plates, tubes, and various moulded objects, using mainly chrysotile asbestos except for tubes where a mixture of chrysotile and crocidolite is used.

Since January 1940 , the few women (4\%) employed have always worked as members of the administrative staff. The factory population, which is geographically stable, has included a few migrant workers $(9 \%)$ who, with the women, have been excluded from the study. As employees with a short duration of employment (specially those first employed many years ago) would have been particularly difficult to trace, the workers selected for the study were those who had been employed for at least five years. The total cohort numbers 1506.

Each worker was followed up from the date of his first employment in the factory (taken as his first 
Table 1 Description of the cohort by age group

\begin{tabular}{|c|c|c|c|c|}
\hline \multirow[t]{2}{*}{ Age } & \multicolumn{2}{|l|}{ No of subjects } & \multicolumn{2}{|c|}{$\begin{array}{l}\text { Man-years of observation as a function of time } \\
\text { elapsed since furst exposure }\end{array}$} \\
\hline & At start of exposure & At end of observation & $\leqslant 20$ & $>20$ \\
\hline $\begin{array}{l}10-14 \\
15-19 \\
20-24 \\
25-29 \\
30-34 \\
35-39 \\
40-44 \\
45-49 \\
50-54 \\
55-59 \\
60-64 \\
65-69 \\
70-74 \\
75-79 \\
80-84 \\
>85\end{array}$ & $\begin{array}{r}130 \\
386 \\
357 \\
185 \\
139 \\
112 \\
81 \\
58 \\
32 \\
22 \\
4\end{array}$ & $\begin{array}{r}3 \\
50 \\
173 \\
211 \\
185 \\
227 \\
214 \\
152 \\
119 \\
67 \\
55 \\
31 \\
11 \\
8\end{array}$ & $\begin{array}{r}86 \cdot 00 \\
1743 \cdot 50 \\
3430.50 \\
4801 \cdot 50 \\
4932.25 \\
3877.75 \\
2965.75 \\
1976 \cdot 25 \\
1473.75 \\
986.75 \\
602.50 \\
322.25 \\
123.50 \\
19.75 \\
0.75\end{array}$ & $\begin{array}{r}63.75 \\
668.75 \\
1169.75 \\
1368 \cdot 50 \\
1040.00 \\
759.00 \\
516.50 \\
373.75 \\
246.50 \\
131.75 \\
60.75 \\
22.75\end{array}$ \\
\hline
\end{tabular}

Table 2 Description of the cohort by time elapsed since first exposure

\begin{tabular}{|c|c|c|c|c|}
\hline \multicolumn{2}{|c|}{$\begin{array}{l}\text { Time elapsed } \\
\text { since 1st } \\
\text { exposure }\end{array}$} & $\begin{array}{l}\text { No of subjects } \\
\text { contributing for } \\
\text { calculation of } \\
\text { man-years* }\end{array}$ & $\begin{array}{l}\text { Man-years of } \\
\text { observation }\end{array}$ & $\begin{array}{l}\text { No of } \\
\text { deaths } \\
99\end{array}$ \\
\hline $\begin{array}{l}>20 \\
>25 \\
>30 \\
>35\end{array}$ & $\begin{array}{l}\leqslant 20 \\
\leqslant 25 \\
\leqslant 30 \\
\leqslant 35\end{array}$ & $\begin{array}{r}1506 \\
941 \\
542 \\
242 \\
118\end{array}$ & $\begin{array}{r}27342 \cdot 75 \\
3581 \cdot 75 \\
1799 \cdot 50 \\
801 \cdot 75 \\
238 \cdot 75\end{array}$ & $\begin{array}{l}99 \\
49 \\
29 \\
19 \\
10\end{array}$ \\
\hline
\end{tabular}

*Each subject observed for more than 20 years (at least $20 \cdot 25$ years) contributes 20 man-years to the class of time elapsed since first exposure less than or equal to 20 years and for the rest of his period of observation to the succeeding five year classes.

exposure to asbestos) up to his death or to the end of the follow up period (31 December 1982) whichever occurred soonest.

Date of birth, dates of beginning and end of employment and date of death (during employment or after retirement) were obtained from the staff register kept up to date for administrative purposes since the foundation of the factory. The eventual date of death for those workers who left the factory before retirement (and therefore were not followed up in the staff register) was obtained by contacting the relatives whenever possible, otherwise by obtaining the information directly from the local registry office. Causes of death were obtained from hospitals and family doctors.

The method used to estimate the mortality risk was "the man-years method"14-16 which allows a comparison to be made between the mortality of a defined group of subjects with the expected mortality that would have occurred had the group experienced the same death rate as that of a standard population, in this case the French male population.

The different dates necessary for calculating the age-time-specific man-years (dates of birth, entry and exit of observation) are expressed in completed quarterly years (January $1940=1940 \cdot 00$, April $1940=1940 \cdot 25$ ); then, man-years are computed in years and quarterly years. Table 1 shows the distribution of the cohort within age-classes and the corresponding man-years and table 2 shows the distribution according to time elapsed since first exposure.

Cancer mortality was analysed in those whose elapsed time since first exposure is over 20 years. For this analysis the cohort (a total of 941) has been subdivided according to the duration of employment: between five and 20 years ( 357 subjects) and more than 20 years $(584)$ (table 3$)$.

The "expected deaths" (based on the age specific death rates for the French male population ${ }^{17-19}$ ) are

Table 3 Description of the cohort by duration of employment more than 20 years after furst exposure

\begin{tabular}{|c|c|c|c|c|c|c|}
\hline \multirow{3}{*}{$\begin{array}{l}\text { Time elapsed since } \\
\text { lst exposure } \\
\text { (years) }\end{array}$} & \multicolumn{6}{|l|}{ Duration of employment (years) } \\
\hline & \multicolumn{3}{|l|}{$5-20$} & \multicolumn{3}{|l|}{$>20$} \\
\hline & $\begin{array}{l}\text { No of subjects contributing to } \\
\text { calculation of man-years }\end{array}$ & $\begin{array}{l}\text { Man-years of } \\
\text { observation }\end{array}$ & $\begin{array}{l}\text { No of } \\
\text { deaths }\end{array}$ & $\begin{array}{l}\text { No of subjects contributing to } \\
\text { calculation of man-years }\end{array}$ & $\begin{array}{l}\text { Man-years of } \\
\text { observation }\end{array}$ & $\begin{array}{l}\text { No of } \\
\text { deaths }\end{array}$ \\
\hline $\begin{array}{l}>20 \leqslant 25 \\
>25 \leqslant 30 \\
>30 \leqslant 35 \\
>35\end{array}$ & $\begin{array}{r}357 \\
196 \\
88 \\
42\end{array}$ & $\begin{array}{r}1327 \cdot 00 \\
645 \cdot 50 \\
291 \cdot 50 \\
91 \cdot 75\end{array}$ & $\begin{array}{r}28 \\
13 \\
9 \\
1\end{array}$ & $\begin{array}{r}584 \\
346 \\
154 \\
76\end{array}$ & $\begin{array}{r}2254 \cdot 75 \\
1154 \cdot 00 \\
510 \cdot 25 \\
147 \cdot 00\end{array}$ & $\begin{array}{r}21 \\
16 \\
10 \\
9\end{array}$ \\
\hline
\end{tabular}


calculated by five year age classes and by five year periods beginning 1 January 1940 for mortality from all causes and beginning 1 January 1960 for mortality from cancer.

The mortality risk is expressed by the standardised mortality ratio (SMR). The significance of the SMR was tested by assuming that, under the null hypothesis, the number of observed deaths originated from a Poisson distribution with mean equal to the number of expected deaths. ${ }^{16}$

Table 4 Distribution of causes of death by time elapsed since furst exposure and by duration of employment more than 20 years after first exposure

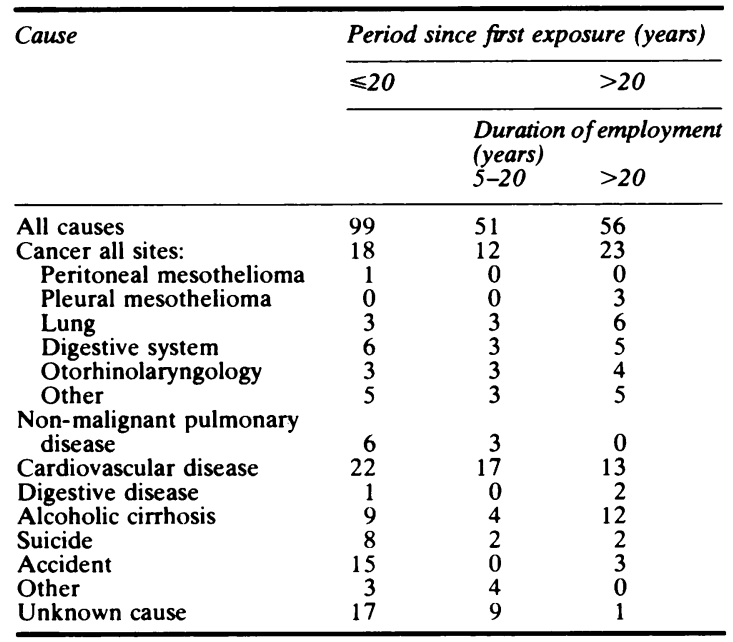

Table 5 SMR from all causes in function of time elapsed since furst exposure

\begin{tabular}{lll}
\hline $\begin{array}{l}\text { Time elapsed since first } \\
\text { exposure (years) }\end{array}$ & $O / E^{*}$ & $S M R$ \\
\hline \multicolumn{1}{c}{$\leqslant 20$} & $99 / 128 \cdot 04$ & $0 \cdot 77 \dagger$ \\
$>20 \leqslant 25$ & $49 / 39 \cdot 74$ & $1 \cdot 23$ \\
$>25 \leqslant 30$ & $29 / 29 \cdot 98$ & $0 \cdot 97$ \\
$>30 \leqslant 35$ & $19 / 20 \cdot 26$ & $0 \cdot 94$ \\
$>35$ & $10 / 6 \cdot 62$ & $1 \cdot 51$ \\
Total $>20$ & $107 / 96 \cdot 60$ & $1 \cdot 11$ \\
\hline
\end{tabular}

${ }^{*}$ Ratio of observed to expected deaths. $t_{\mathrm{p}}<0.01$.
Results

We had no loss to follow up and 206 deaths occurred in the cohort during the study period. Of those, it was possible to identify the cause of death for 179 subjects $(87 \%)$. The causes of death are listed in table 4 according to the time elapsed since first exposure and, for those that occurred more than 20 years after first exposure, according to duration of employment.

\section{OVERALL MORTALITY}

Table 5 shows the observed and expected number of deaths and the SMRs. In subjects from whom the time since first exposure does not exceed 20 years a SMR value of 0.77 , significantly less than 1 , was observed. There was no significant excess mortality in the subcohorts with an observation duration exceeding 20 years when the duration of employment was not taken into account. When it was, however, it may be seen (table 6) that in workers with less than 20 years' employment the SMRs are not significantly different from 1 and the overall SMR value is 1.00 , whereas in workers with more than 20 years' employment the overall SMR value is $1 \cdot 22$. The highest SMR (SMR $=2 \cdot 33$, significantly greater than 1) was found in workers whose time since first exposure was the longest.

\section{CANCER MORTALITY}

The deaths from mesothelioma and from lung cancer are detailed in table 7 . The four deaths from mesothelioma were one from peritoneal mesothelioma occurring less than 20 years after first exposure and three from pleural mesothelioma occurring more than 20 years after first exposure. The average latent period is close to 25 years. As regards lung cancer, three deaths occurred less than 20 years after first exposure, with an average latency of 13 years and nine occurred more than 20 years after the first exposure, with an average latency of $25 \frac{1}{2}$ years. The mortality rates for lung cancer and mesothelioma were estimated by age group and the results are shown in table 8 . For lung cancer, the

Table 6 SMR all causes, within employment duration more than 20 years after furst exposure

\begin{tabular}{|c|c|c|c|c|}
\hline \multirow[t]{3}{*}{ Time since Ist exposure (years) } & \multicolumn{4}{|c|}{ Employment duration (years) } \\
\hline & \multicolumn{2}{|l|}{$5-20$} & \multicolumn{2}{|l|}{$>20$} \\
\hline & $O / E$ & $S M R$ & $O / E$ & $S M R$ \\
\hline $\begin{array}{l}>20 \leqslant 25 \\
>25 \leqslant 30 \\
>30 \leqslant 35 \\
>35 \\
\text { Total }>20\end{array}$ & $\begin{array}{c}28 / 22 \cdot 19 \\
13 / 15 \cdot 77 \\
9 / 10 \cdot 10 \\
1 / 2 \cdot 75 \\
51 / 50 \cdot 81\end{array}$ & $\begin{array}{l}1 \cdot 26 \\
0.82 \\
0.89 \\
0.36 \\
1.00\end{array}$ & $\begin{array}{c}21 / 17 \cdot 56 \\
16 / 14 \cdot 21 \\
10 / 10 \cdot 16 \\
9 / 3 \cdot 87 \\
56 / 45 \cdot 80\end{array}$ & $\begin{array}{l}1 \cdot 20 \\
1 \cdot 13 \\
0 \cdot 98 \\
2 \cdot 33^{*} \\
1 \cdot 22\end{array}$ \\
\hline
\end{tabular}

${ }^{*} \mathrm{p}<0.05$ (assuming a Poisson distribution). 
highest death rate was in those aged 65 and over; for mesothelioma, it was in the 45-54 age group.

Considering only subjects who have been followed up for more than 20 years since first exposure (table 9), no excess mortality occurs in those with the shortest duration of employment (5-20 years). For those with more than 20 years of employment, a significant excess mortality from cancer of all sites (SMR = 1.68) was noted; there was no excess of death from causes other than cancer $(S M R=1 \cdot 03)$.

\begin{tabular}{|c|c|c|}
\hline \multirow[t]{2}{*}{ Causes } & \multicolumn{2}{|c|}{ Time elapsed since first exposure (years) } \\
\hline & $\leqslant 20$ & $>20$ \\
\hline $\begin{array}{l}\text { Mesothelioma: } \\
\text { No } \\
\text { Average age at onset of exposure } \\
\text { Average age at death } \\
\text { Latency period }\end{array}$ & $\begin{array}{l}1^{*} \\
28 \\
41 \cdot 5 \\
13 \cdot 5\end{array}$ & $\begin{array}{l}3 \dagger \\
21 \cdot 8(\text { range }=16 \cdot 3-26 \cdot 0) \\
46.5(\text { range }=41 \cdot 8-52 \cdot 5) \\
24 \cdot 8(\text { range }=22 \cdot 3-26 \cdot 5)\end{array}$ \\
\hline $\begin{array}{l}\text { Lung cancer (ICD: } 162 \text { ): } \\
\text { No } \\
\text { Average age at onset of exposure } \\
\text { Average age at death } \\
\text { Latency period }\end{array}$ & $\begin{array}{l}3 \\
37 \cdot 3(\text { range }=18-49 \cdot 5) \\
50 \cdot 6(\text { range }=37-64) \\
13 \cdot 3(\text { range }=6 \cdot 3-19)\end{array}$ & $\begin{array}{l}9 \\
30 \cdot 3(\text { range }=18 \cdot 5-43) \\
56 \cdot 0(\text { range }=46 \cdot 8-71 \cdot 3) \\
25 \cdot 7(\text { range }=21 \cdot 3-30 \cdot 5)\end{array}$ \\
\hline
\end{tabular}

*Peritoneal mesothelioma.

†Pleural mesothelioma.

Table 8 Lung cancer and mesothelioma death rates by age group, in function of time elapsed since first exposure

\begin{tabular}{|c|c|c|c|c|c|}
\hline \multirow{2}{*}{$\begin{array}{l}\text { Cause } \\
\text { Time elapsed since 1st exposure } \\
\text { (years) }\end{array}$} & \multicolumn{5}{|l|}{ Age } \\
\hline & $35-44$ & $45-54$ & $55-64$ & $\geqslant 65$ & Total \\
\hline \multicolumn{6}{|l|}{$\begin{array}{l}\text { Lung cancer: } \\
\leqslant 20\end{array}$} \\
\hline $\begin{array}{l}\text { No } \\
\text { Rate } \ddagger\end{array}$ & $\begin{array}{l}1 \\
0 \cdot 15\end{array}$ & $\begin{array}{l}1 \\
0 \cdot 30\end{array}$ & $\begin{array}{l}1 \\
0.63\end{array}$ & $\underline{0}$ & $\begin{array}{l}3 \\
0 \cdot 24\end{array}$ \\
\hline $\begin{array}{l}>20 \\
\text { No } \\
\text { Rate } \neq \\
1970 \text { rate } \ddagger\end{array}$ & $\frac{0}{0.09}$ & $\begin{array}{l}5 \\
2.08 \\
0.36\end{array}$ & $\begin{array}{l}2 \\
1 \cdot 57 \\
1 \cdot 25\end{array}$ & $\begin{array}{l}2 \\
2 \cdot 39 \\
2 \cdot 11\end{array}$ & $\begin{array}{l}9 \\
1.42\end{array}$ \\
\hline $\begin{array}{l}\text { Mesothelioma: } \\
\leqslant 20\end{array}$ & & & & & \\
\hline $\begin{array}{l}\text { No } \\
\text { Rate } \neq \\
>20\end{array}$ & $\begin{array}{l}1 \dagger \\
0 \cdot 15\end{array}$ & $\underline{0}$ & $\frac{0}{-}$ & $\underline{0}$ & $\begin{array}{l}1 \\
0.08\end{array}$ \\
\hline $\begin{array}{l}\text { No } \\
\text { Ratef }\end{array}$ & $\begin{array}{l}1^{*} \\
0 \cdot 54\end{array}$ & $\begin{array}{l}2^{*} \\
0.83\end{array}$ & $\underline{0}$ & 0 & $\begin{array}{l}3 \\
0 \cdot 47\end{array}$ \\
\hline
\end{tabular}

*Pleural mesothelioma.

†Peritoneal mesothelioma.

$\ddagger$ Rates for 1000 person-years.

Table 9 SMR from causes within employment categories more than 20 years after furst exposure

\begin{tabular}{|c|c|c|c|c|c|c|}
\hline \multirow[t]{3}{*}{ Cause } & \multicolumn{6}{|c|}{ Employment duration (years) } \\
\hline & \multicolumn{2}{|l|}{$5-20$} & \multicolumn{2}{|l|}{$>20$} & \multicolumn{2}{|l|}{ Total } \\
\hline & $\overline{O / E}$ & SMR & $\overline{O / E}$ & $S M R$ & $\overline{O / E}$ & $S M R$ \\
\hline $\begin{array}{l}\text { Cancers all sites } \\
\text { (ICD 140-209) }\end{array}$ & $12 / 12 \cdot 82$ & 0.94 & $23 / 13 \cdot 72$ & $1 \cdot 68^{*}$ & $35 / 26 \cdot 54$ & $1 \cdot 32$ \\
\hline $\begin{array}{l}\text { Causes other than cancers } \\
\text { Pulmonary cancers } \\
(\text { ICD } 162-163 \cdot 0)\end{array}$ & $\begin{array}{c}39 / 37.99 \\
3 / 2 \cdot 51\end{array}$ & $\begin{array}{l}1 \cdot 03 \\
1 \cdot 20\end{array}$ & $\begin{array}{c}33 / 32.08 \\
9 / 3.01\end{array}$ & $\begin{array}{l}1.03 \\
2.99 \dagger\end{array}$ & $\begin{array}{l}72 / 0.07 \\
12 / 5 \cdot 52\end{array}$ & $\begin{array}{l}1 \cdot 03 \\
2 \cdot 17^{*}\end{array}$ \\
\hline Cancers other than pulmonary & $9 / 10 \cdot 01$ & 0.87 & $14 / 10 \cdot 71$ & $1 \cdot 30$ & $23 / 21 \cdot 02$ & 1.09 \\
\hline
\end{tabular}


Table 10 SMR from cancers (all sites and pulmonary) in function of employment and age at first exposure

\begin{tabular}{|c|c|c|c|c|c|c|c|}
\hline \multirow[t]{3}{*}{ Cause } & \multirow{3}{*}{$\begin{array}{l}\text { Age at 1st } \\
\text { exposure }\end{array}$} & \multicolumn{6}{|c|}{ Employment duration (years) } \\
\hline & & \multicolumn{2}{|l|}{$5-20$} & \multicolumn{2}{|l|}{$>20$} & \multicolumn{2}{|l|}{ Total } \\
\hline & & $O / E$ & $S M R$ & $O / E$ & $S M R$ & $O / E$ & $S M R$ \\
\hline $\begin{array}{l}\text { Cancers all sites } \\
(140-209) \\
\text { Pulmonary cancers } \\
(162-163 \cdot 0)\end{array}$ & $\begin{array}{l}\leqslant 25 \\
>25 \\
\leqslant 25 \\
>25\end{array}$ & $\begin{array}{l}5 / 1 \cdot 99 \\
7 / 10 \cdot 83 \\
1 / 0 \cdot 41 \\
2 / 2 \cdot 10\end{array}$ & $\begin{array}{l}2.51 \\
0.65 \\
2.43 \\
0.93\end{array}$ & $\begin{array}{c}10 / 3 \cdot 68 \\
13 / 10 \cdot 04 \\
4 / 0.77 \\
5 / 2 \cdot 24\end{array}$ & $\begin{array}{l}2 \cdot 72^{*} \\
1 \cdot 29 \\
5 \cdot 19^{*} \\
2 \cdot 23\end{array}$ & $\begin{array}{c}15 / 5 \cdot 67 \\
20 / 20 \cdot 87 \\
5 / 1 \cdot 18 \\
7 / 4 \cdot 34\end{array}$ & $\begin{array}{l}2 \cdot 67 \dagger \\
0.96 \\
4 \cdot 23^{*} \\
1.61\end{array}$ \\
\hline
\end{tabular}

${ }^{*} \mathrm{p}<0.01$

$t_{\mathrm{p}}<0.001$.

duration of employment. The results (table 10) show that the SMRs are also higher in people hired before the age of 25 . The greatest value (SMR = $5 \cdot 19)$ was obtained for pulmonary cancer in those who were first hired before the age of 25 and employed for more than 20 years.

\section{Discussion}

\section{GENERAL MORTALITY}

The SMR $(0 \cdot 77)$ for those whose duration of exposure is less than or equal to 20 years illustrates the phenomenon of the healthy worker effect; a similar result was found by Selikoff $e t$ al in insulation workers. ${ }^{2}$ Among subjects whose time since first exposure is greater than 20 years the risk is greater in those with the longest time since first exposure. The SMR for the entire cohort followed up for more than 20 years since first exposure $(1 \cdot 11)$ is lower than that obtained by Selikoff $e t$ al in insulation workers $(\mathrm{SMR}=1.41)^{2}$ or that estimated by Finkelstein in asbestos cement workers (SMR $=2 \cdot 0)^{13}$; it is close to that evaluated from the results of McDonald et al in chrysotile mine workers in Quebec (SMR approximately $1 \cdot 1$ for the categories of "gross service" over five years) ${ }^{4}$; it is much higher than that estimated from the results of Hughes and Weill in asbestos cement workers, approximately 0.7 , but in that study about $60 \%$ of workers had been employed for less than one year. ${ }^{10}$

\section{CANCER MORTALITY}

The results presented here are limited by the quality of the information on the causes of death. For the complete cohort, the total number of non-identified causes is greater in the subjects whose employment was less than 20 years ( 26 of the 27 non-identified deaths) and, among them, in those who began to work a long time ago ( 23 non-identified deaths occurred in subjects having entered the factory before 1960 and stayed less than 20 years). Among those with more than 20 years since first exposure it is in the group with short duration of employment that most of the non-identified causes of death occurred (9/1). With regard to the quality of the information, the physician who collected the data was in a privileged position to obtain first hand information. The son of the medical practitioner in Digoin, he was himself a practitioner in Paray-leMonial for 25 years. The factory is between these two towns, which are within seven miles of each other. This was a considerable advantage when contacting the families, hospital and regional doctors, and neighbouring town halls. As mentioned before the French method of registering deaths does not provide the cause of individual deaths. Nevertheless, had we obtained the death certificates, the nonidentified causes would have been $9 \%$ in the 35-39 year age group to $16 \%$ in the $85-89$ year age group ${ }^{20}$ instead of the $9 \%$ in those of our subjects observed for more than 20 years-that is, in the subjects studied for mortality from cancer at all sites and pulmonary cancer.

For cancers at all sites, in the subjects with more than 20 years' employment, our SMR of 1.68 (significantly greater than 1) is higher than that obtained by McDonald et al in chrysotile mine workers (SMR y 1.2 for "gross service" greater than 20 years). ${ }^{4}$ The SMR for our entire cohort 20 years after first exposure (SMR = 1.32), however, is less than half that found by Selikoff $e t$ al in insulation workers $(\mathrm{SMR}=3.05),{ }^{2}$ and more than three times lower than that estimated by Finkelstein in asbestos cement workers in Ontario $(\mathrm{SMR}=4 \cdot 6) .{ }^{13}$ The deaths of unknown cause could not affect our results for cancer at all sites when one considers that, for the group of subjects observed for more than 20 years, only 10 causes were not characterised. In the most pessimistic hypothesis, which would consider that all unknown deaths were from cancers, there would be nine supplementary cancers in the class with the shortest duration of employment, and one in the other, which would result in SMR values of 1.64 and 1.75 respectively; taking the mean hypothesis, which would consider that the same proportion of cancers at all sites exists among the identified and non-identified causes, then the SMR values for those with the shortest duration of emp- 
loyment would be $1 \cdot 14$ and 1.71 for those with the longest employment. The SMR estimated for pulmonary cancer in people whose elapsed time since first exposure is greater than 20 years $(\mathrm{SMR}=2 \cdot 17$, significantly greater than 1) is nearly four times lower than the one assessed by Finkelstein for lung cancer alone (ICD 162) - but this latter study was made with a small number of subjects. ${ }^{13}$ On the other hand, it is higher than that estimated by Hughes and Weill in people whose duration of employment exceeded two years (assessed risk close to 1.5). ${ }^{10}$ The risk that we have estimated in people employed more than 20 years (SMR $=2 \cdot 99)$ is significantly greater than 1 , which is higher than the SMR found by McDonald et al in chrysotile miners with "gross service" of more than or equal to 20 years $(\mathrm{SMR}=1.61)^{4}$ and close to that evaluated by Henderson and Enterline $(S M R=2.70)$ for retired people whose average duration of employment was 25 years." The excess mortality from cancer at all sites found in the present study may be explained by the excess mortality observed for respiratory cancer since for cancers other than respiratory, there is no compensatory decrease in mortality.

In all cases for the same duration of employment SMRs are higher in those whose age at first exposure does not exceed 25. We may quote Peto et al, "lifelong regular exposure of humans to a carcinogenic insult will be more dangerous the younger exposure starts." ${ }^{20}$ We may assume that asbestos is never entirely eliminated from the organism.

Despite the eventual underestimate, due to the existence of 10 non-determined causes of death, it is interesting to note that the lung cancer mortality rates calculated for our cohort, in subjects observed from more than 20 years in the age groups 45-54, $55-64$, and 65 and more, are higher than those in the French male population for the year 1970 with the greatest difference (nearly six times as great) being found in those aged 45-54 (table 8).

A remark must be made in the case of the mesotheliomas: we have observed four deaths (a proportional mortality of $2 \%$ ) for which the latent period is not very long: less than 14 years for the death from peritoneal mesothelioma and an average of less than 25 years from the three deaths from pleural mesothelioma. Selikoff et al observed 175 cases of mesothelioma in 2271 deaths $(8 \%)$ and the highest incidence appeared about 40 years after the onset of exposure..$^{21}$ So possibly in our case the average time elapsed since first exposure is not long enough - a mean of 22.4 years, with only 118 men observed for more than 35 years since the onset of exposure to appreciate the full impact of the exposure $^{21}$ and that what we observe here are the early deaths from mesothelioma. The latent period for pleural tumours, however, is greater than that observed by Hughes and Weill who suggested that "the latent period for the development of asbestos related malignant disease may be less than 20 years." ${ }^{10}$ With the exception of one of these subjects who died from pleural mesothelioma, all were in contact with crocidolite dust during the whole duration of their employment. The number of deaths by mesothelioma could have been underestimated because 27 causes of death were unidentified. It seems unlikely, however, that we could not have been warned of deaths from this cause during our inquiry, because the respondents, all located within the region containing the factory, were very aware of the risks of mesothelioma.

In conclusion, our work has shown an excess mortality from cancer of all sites in subjects whose duration of employment exceeded 20 years and who were hired before the age of 25 . This excess may be explained by an excess of deaths from pulmonary cancer (lung and pleura). We have no evidence for an excess of deaths from cancer in subjects who have worked less than 20 years, but in this group deaths from cancer may have been underestimated.

We gratefully acknowledge Dr Badin and Mrs Magnin, the physician and the nurse in charge of the workers who are analysed in this report. This work could not have existed without their active cooperation.

This study was supported by Grant INSERMCNAMTS - 1982-17-02.

\section{References}

I Newhouse M. Epidemiology of asbestos-related tumors. Semin Oncol 1981;8:250-7.

2 Selikoff IJ, Hammond EC, Seidman H. Mortality experience of insulation workers in the USA and Canada 1943-1976. Ann NY Acad Sci 1979;330:91-116.

${ }^{3}$ Hammond EC, Selikoff IJ, Seidman H. Asbestos exposure, cigarette smoking and death rates. Ann NY Acad Sci 1979;330:473-90.

${ }^{4}$ McDonald JC, Liddell FDK, Gibbs GW, Eyssen GE, McDonald AD. Dust exposure and mortality in chrysotile mining 1910 75. Br J Ind Med 1980;37:11-24.

${ }^{5}$ McDonald JC. Asbestos-related disease: an epidemiological review. Lyon: International Agency for Research on Cancer, 1980:587-601. (IARC scientific pub No 30, vol 2.)

- Selikoff IJ, Seidman H. Cancer of the pancreas among asbestos insulation workers. Cancer 1981;47:1469-73.

7 Newhouse ML, Gregory MM, Shannon H. Etiology of carcinoma of the larynx. Lyon: International Agency for Research on Cancer, 1980:687-93. (IARC scientific pub No 30, vol 2.)

${ }^{8}$ Health hazards of asbestos exposure. Ann NY Acad Sci $1979 ; 330$.

International Agency for Research on Cancer. Biological effects of mineral fibers. Lyon: IARC, 1980. (IARC scientific pub No 30, vols 1 and 2.)

${ }^{10}$ Hughes J, Weill H. Lung cancer risk associated with manufacture of asbestos-cement products. Lyon: International Agency for Research on Cancer, 1980:627-35. (IARC scientific pub No 
30, vol 2.)

"Henderson VL, Enterline PE. Asbestos exposure: factors associated with excess cancer and respiratory disease mortality. Ann NY Acad Sci 1979;330:117-26.

${ }^{12}$ Lacquet LM, Van Der Linden. Roentgenographic lung changes, asbestosis and mortality in a Belgian asbestos-cement factory. Lyon: International Agency for Research on Cancer, 1980:783-93. (IARC scientific pub No 30, vol 2.)

${ }^{13}$ Finkelstein MM. Mortality among long-term employees of an Ontario asbestos-cement factory. $\mathrm{Br} J$ Ind Med 1983;40: 138-44.

${ }^{14}$ Case RAM, Lea AJ. Mustard gas poisoning, chronic bronchitis and lung cancer. Br J Prev Soc Med 1955;9:62-72.

is Liddell FDK, McDonald JC, Thomas DC. Methods of cohort analysis: appraisal by application to asbestos mining. Journal of the Royal Statistical Society series A 1977;140:469-91.

${ }^{16}$ Berry G. The analysis of mortality by the subject-years method. Biometrica 1983;39:173-84.

17 Institut National de la Statistique et des Etudes Economiques. Statistique des causes de décès. Paris 1942 and 1947.

${ }^{18}$ Institut National de la Statistique et des Etudes Economiques. Aperçu rétrospectif. Anneés 1950-1967. Paris.

${ }^{14}$ Institut National de la Santé et de la Recherche médicale. Statistique des causes de décès. Paris 1968-1977.

${ }^{20}$ Peto R, Roe FJC, Lee PN, Levy L, Clack J. Cancer and ageing in mice and men. Br J Cancer 1975;32:411-26.

2" Selikoff IJ, Hammond EC, Seidman H. Latency of asbestos disease among insulation workers in the UK and Canada. Cancer 1980;46:2736-40. 